\title{
Percepcja edukacji seksualnej przez osoby z niepełnosprawnością intelektualną w stopniu głębszym
}

\section{Perception of sexual education of people with moderate, severe and profound intellectual disabilities}

The presented article is devoted to the perception of sexual education of people with moderate, severe and profound intellectual disabilities. It appears an interesting phenomenon which however has not been explored enough either in theoretical or empirical context. Over the past several years the needs of people with intellectual disabilities have been noticed by the society, concentrating not only on the basic ones but also emphasizing those which satisfy the sphere of independent and valuable life. However, perception of these properties does not guarantee their acceptance and help to realize them. Hence, the article also discusses the aspect of normalization of people with intellectual disabilities.

Słowa kluczowe: osoba z niepełnosprawnością intelektualną, percepcja społeczna, edukacja seksualna

Keywords: Person with intellectual disabilities, social perception, sexual education

\section{Wprowadzenie}

Prezentowany artykuł koncentruje się na kwestii problemowej dotyczącej percepcji edukacji seksualnej przez osoby z niepełnosprawnością intelektualną w stopniu głębszym. Jest to dla mnie interesujące zagadnienie pod względem naukowym, które nadal nie zostało zgłębione empirycznie i teoretycznie. Na przestrzeni ostatnich kilkunastu lat społeczeństwo zaczęło zauważać potrzeby osób z niepełnosprawnością intelektualną, które skupiają się nie tylko na zaspokojeniu ich podstawowych funkcji życiowych, ale także zapewniają im prawo do samodzielnego, wartościowego życia. Jednak dostrzeżenie owych właściwości nie 
gwarantuje ich akceptacji i pomocy związanej z ich realizacją. Tym samym artykuł w dużej mierze porusza aspekt normalizacji życia osób z niepełnosprawnością intelektualną.

W dyskusji społecznej większą uwagę poświęca się kwestiom związanym $\mathrm{z}$ uświadomieniem społeczeństwa na temat specyfiki funkcjonowania osób z niepełnosprawnością intelektualną. Ukazując także, iż owi członkowie społeczeństwa nie są ludźmi odmiennymi pod względem potrzeb związanych z ich seksualnością. Pomimo wszelkich naukowych rozważań brakuje systemowych rozwiązań jakim może być m.in. wprowadzenie edukacji seksualnej do placówek, w których nabywają umiejętności osoby z niepełnosprawnością intelektualną. Społeczne postawy negacji i braku zrozumienia dla sfery seksualności owych osób, skutkują niemożnością wyrażania swoich potrzeb i uczuć przez osoby z niepełnosprawnością intelektualną.

W przeprowadzonych badaniach chciałam zobrazować nie tylko odczucia osób z niepełnosprawnością intelektualną związane z przeprowadzonymi warsztatami dotyczącymi ich seksualności z dr Izabelą Fornalik. Moim celem było także zobrazowania znaczeń jakie osoby z niepełnosprawnością intelektualną w stopniu głębszym nadają poszczególnym zagadnieniom związanym bezpośrednio z szeroko pojętą seksualnością. Istotną dla mnie kwestią był również poziom rozumienia przedstawianych treści przez uczestników szkolenia i odniesienia ich do życia codziennego. W swojej pracy zawarłam także subiektywne odczucia terapeutek, pracujących z osobami, które uczestniczyły w wymienionym wcześniej szkoleniu. Ważną dla mnie kwestią było również ukazanie, jakie prezentują postawy względem seksualności swoich podopiecznych.

Prezentowane badanie odbyło się na terenie Warsztatu Terapii Zajęciowej w Gdańsku prowadzonego przez Polskie Stowarzyszenie na Rzecz Osób z Upośledzeniem Umysłowym, koło w Gdańsku. W 2015 roku wybrani uczestnicy warsztatu mieli szansę wzięcia udziału w szkoleniu prowadzonym przez dr Izabelę Fornalik, a dotyczącego seksualności osób z niepełnosprawnością intelektualną.

W swoich badaniach posłużyłam się metodą indywidualnych przypadków, przeprowadzając wywiady częściowo skategoryzowane z pięcioma uczestnikami wyżej przedstawionych zajęć. Przedział wiekowy badanych to 24 do 35 lat. W badaniu uczestniczyły 2 kobiety i 3 mężczyzn.

Organizowane warsztaty składały się z dwóch etapów. Pierwszy z nich składał się z 3-dniowych zajęć, na których to osoby z niepełnosprawnością intelektualną dowiadywały się m.in. podstawowych informacji o budowie ciała kobiety i mężczyzny, radzeniu sobie z własnym napięciem seksualnym, a także z czym wiąże się opieka nad potomstwem.

Kolejny etap obejmował zajęcia, na które byli zapraszani terapeuci z poszczególnych placówek. Celem tychże spotkań było przybliżenie technik pomocy oso- 
bom $\mathrm{z}$ niepełnosprawnością intelektualną $\mathrm{w}$ przeżywaniu ich seksualności w społecznie akceptowany sposób, z jednoczesnym poszanowaniem potrzeb i prywatności samych zainteresowanych. Chcąc poznać opinie i postawy terapeutów dotyczących edukacji seksualnej osób z niepełnosprawnością intelektualną przeprowadziłam częściowo skategoryzowane wywiady z dwójką z nich.

Każda z przeprowadzonych przez mnie rozmów odznaczała się inną ekspresją i formą wypowiedzi badanych, co bezpośrednio wynika z poziomu funkcjonowania danych osób, ale także uwarunkowane jest indywidualnymi cechami osobowościowymi moich rozmówców.

\section{Znaczenia nadawane seksualności przez osoby z niepełnosprawnością intelektualną w stopniu głębszym.}

Znaczenia, jakie przypisują ludzie seksualności, odnoszą się nie tylko to rozumienia i podania definicji pewnych kwestii dotyczących sfery intymnej. Istotny przedmiot owego przypisywania znaczeń warunkuje także ocena własnej tożsamości płciowej oraz identyfikowania jej do konkretnych ról społecznych. Kolejny ważny element obejmuje reprezentowane nastawienie do własnej seksualności, co $\mathrm{w}$ dużej mierze warunkuje poziom samooceny, a także sposób postrzegania niektórych zagadnień związanych z szeroko pojętą seksualnością. Dlatego też starając się przedstawić, jakie znaczenia nadają osoby z niepełnosprawnością intelektualną w stopniu głębszym na podstawie przeprowadzonych wywiadów, swoje pytania oparłam na wyżej opisanych kwestiach, które nie tylko pełniły funkcję porządkową wywiadu, ale także stały się istotnym elementem analizy zebranego materiału empirycznego.

Przechodząc do konkretnego przeglądu badań odnośnie do kwestii wiedzy na temat własnej seksualności badanych mogę jasno stwierdzić, iż wszystkie osoby orientowały się jakiej są płci. Posiadały stereotypowy pogląd dotyczący pełnienia ról społecznych. Rola kobiety była sprowadzona do opieki nad dziećmi lub też do jedynie emanowania swoją kobiecością. Zaś mężczyzna w opinii badanych musiał zarabiać na utrzymanie rodziny. Wszelkie zagadnienia dotyczące dojrzewania oraz różnicowania pod względem płciowym kobiety i mężczyzny wywoływały u badanych poczucie zawstydzenia bądź też śmiechu.

(W. 3) „No yyy Marta nie raz mi mówiła, macica? Nie... macica jest, wargi stromotne, no i zapomniałam (śmiech)".

Badani reprezentowali różny poziom wiedzy na temat okresu adolescencji i związanych z nim zjawisk. Może to świadczyć o braku uświadomienia bądź też nazywania konkretnych zmian jakie zachodziły $w$ ich organizmach. W swoich 
wypowiedziach żadna z osób nie odniosła się do własnego doświadczenia związanego z przeżywania okresu dojrzewania.

(W. 2) „Aaa...nie jestem pewna, ale chyba menopauza albo albo może mieć miesiączkę. (...)”.

(W. 1) "Dojrzewać znaczy mężczyzna, to jest wtedy przesilenie wiosenne".

Na zagadnienie dotyczące cech różnicujących mężczyznę od kobiety większość badanych odpowiadała konkretnie i rzeczowo, w dużej mierze skupiając się na aspekcie fizyczności obu płci. Jednak został także zauważony aspekt związany z codziennością i doświadczeniami badanego.

(W.4) „Na pewno płeć... dtugość włosów, że dziewczyna maluje paznokcie, a chłopak nie (...) że dziewczyna więcej czasu spędza w tazience niż chłopak".

Kwestie dotyczące rozumienia zagadnień dotyczących seksualności przysparzały badanym więcej trudności. Odnosiły się one do sformułowania konkretnej odpowiedzi, bądź też z brakiem wiedzy i zrozumienia danej kwestii. Wywoływało to u nich uczucie skrępowania i zdenerwowania niemożnością przekazania swojej opinii na dany temat. Większość z osób odnosiła się do swoich doświadczeń, rodzinnych historii bądź też oglądanych przez nich filmów fabularnych.

Termin seksu pojmowany był jako przyjemne doznanie. Owe spostrzeżenie jest oparte w jednym przypadku na prawdziwych doświadczeniach, w innym zaś badany swoje przypuszczenia wnioskował na podstawie filmów oglądanych w Internecie. Swoją definicję przedstawił odnosząc się do technicznych kwestii stosunku.

(W.5) "Seks to jest jak mężzzyzna wkłada penisa do pochwoy i z tego są dzieci”.

Jedna z kobiet wypowiadających się pojmuje pojęcie seksu jako możliwość spania kobiety i mężczyzny w jednym łóżku. Może to świadczyć o braku doznań o takim charakterze bądź też uczuciem wstydu związanym z zdanym pytaniem. Kolejny rozmówca szczerze przyznaje, że nie współżył jeszcze z inną osobą, stąd nie jest $\mathrm{w}$ stanie ustosunkować się do danego pytania.

Podejmowane przez niektórych badanych zachowania seksualne, które zostały ujawnione w rozmowie najczęściej skupiają się na pocałunkach oraz na obejmowaniu partnera. Jedyną osobą, która jawni mówiła o współżyciu z partnerem była kobieta mieszkająca w mieszkalnictwie wspomaganym. $Z$ jej relacji wynika, iż nie jest to jej pierwszy partner seksualny. $Z$ kontekstu wypowiedzi można także wywnioskować próbę prawdopodobnego wykorzystania seksualnego przez jednego z kolegów.

(W.2) „(...) przyszedt a ja odmówiłam. Musiałam się leczyć, żeby do tej mojej waginy to musiałam mieć tabletki, bo inaczej bym się nigdy nie nauczyła. (...) Mnie raz rozebrano... Jezus nie chce nawet o tym myśleć w ogóle. Bo raz miałam rozmowę, ktoś nas nakrył i ja dostałam. Potem to się ten mój dowiedział (...)". 
Badani wykazywali się znajomością pojęcia antykoncepcja. Opisywali je głównie jako zabezpieczenie przez posiadaniem dzieci.

(W.5) „To sa takie środki... kobieta się zabezpiecza przed ciąż??"

Kwestia związana z profilaktycznym wykonywaniem badań kontrolnych została zbagatelizowana przez grupę mężczyzn. Tylko jeden z nich umiał nazwać profesję lekarza odpowiedzialnego za leczenie męskich narządów rozrodczych. Wszyscy badani przyznali, że nigdy nie byli u takiego lekarza. W przypadku kobiet, obydwie panie miały świadomość do jakiego lekarza powinny się udać w celu odbycia badań kontrolnych. Jednak tylko jedna z nich robi to w sposób regularny, gdyż przyjmuję antykoncepcję. W rozumieniu osób badanych ginekolog to osoba, do której przychodzą kobiety, które nie chcą mieć dzieci. Został pominięty aspekt profilaktycznego badania narządów rodnych kobiety, nie tylko w celu przepisania odpowiedniego środka antykoncepcyjnego.

Wszyscy rozmówcy byli w stanie wytłumaczyć znaczenie higieny osobistej oraz wyrażali opinię, iż jest ona istotna w życiu człowieka. Analizując wypowiedzi mogę stwierdzić, iż w opinii badanych dbanie o własne ciało warunkuje sposób postrzegania nas przez inne osoby ze społeczeństwa. Definiowali higienę osobistą jako zabieg mycia się, gdy jest się brudnym.

(W.5) „Trzeba o nia dbać, podmywać się, ważna jest..."

(W.1) "Żeby dbać, golenie, (...) żeby tadnym być".

Jedna z osób zwraca także uwagę na kwestię dbania o higienę osobistą jako profilaktyka przez infekcjami miejsc intymnych.

(W.2) "(...) to kapanie się, no dbanie o to żeby yyy bielizna była czysta i zmienianie jej codziennie, no bo wtedy jest świeżo, może tam odpoczać wszystko, no i żeby było to w ten sposób żeby nie byto infekcji, to trzeba się myć regularnie".

Kolejną kwestię, jaką podałam rozważaniu, jest reprezentowanie przez osoby $\mathrm{z}$ niepełnosprawnością intelektualną $\mathrm{w}$ stopniu głębszym nastawienia do własnej seksualności.

Większość z osób wypowiadających chętnie odpowiadała na pytania dotyczące ich zewnętrznego wyglądu. Niektórzy z nich wyrażali chęć zmiany fizycznych cech oraz zmiany postawy w stosunku do płci przeciwnej.

(W.2) "(...) muszę się pozmieniać... to znaczy w sensie, żeby też nie przeklinać no, trochę z szacunkiem do chłopaków. (...) W wyglądzie... no na przyktad ciało, bym chciała zmienić fryzurę".

Trzy z badanych osób potwierdziły, iż uważają się za atrakcyjne osoby. Wnioskują o tym na podstawie przekazów uzyskanych ze strony społeczeństwa.

(W.3) "Noo jestem ładna, każdy mi tak mówi w mieszkalnictwie, że ładna jestem”. 
Pozostali dwaj rozmówcy nie posiadają zdania odnośnie do postrzegania ich przez rówieśników.

Osoby pozostające $\mathrm{w}$ związkach partnerskich wykazują w swoich wypowiedziach dbałość o wygląd zewnętrzny.

(W.1) "Myję się, no też golić czasem się też golę”. (W.3) „No dbam dzisiaj się akurat musiatam wykapać (...) Maluje się malowidłami, lubię się malować".

Trzy osoby ujawniły, iż są w stałych związkach partnerskich. Pozostałe dwie osoby nie wyrażały chęci związanej ze związanej się z inną osobą. Byli to ci sami rozmówcy, którzy nie widzieli zasadności w zakładaniu rodziny. Zapytani o powód swojej decyzji odpowiedzieli, iż

(W.5) "Yyy... żeby się któcić...eee to niee”. (W.4) „(...) to co się wtedy stato... to mi się na razie nie chce".

Istota małżeństwa rozumiana jako możliwość założenia rodziny i usamodzielnienia się od bliskich. Poruszane są także zagadnienia związane ze wzajemnymi relacjami w związku, które umożliwiają zawarcie związku małżeńskiego. W wypowiedziach badanych brak jest refleksji dotyczącej istoty zalegalizowania związku. Ich uwagi koncentrują się w głównej mierze na formalnych kwestiach.

(W.3) „No małżeństwo to jest na przykład, że ktoś no nie wiem... to, że ktoś bierze ślub nie? No i potem rodza się dzieci i tak dalej..."

(W.3) „(...) Jak to tam ksiądz mówi... jesteście mężem i żoną wtedy tam się catują czy coś i wtedy obraczki i wtedy już jest ślub zagwarantowany, pieniądze już są zaptacone i to wszystko i wtedy jest jeszcze zabawa do rana".

W wyżej przytoczonej wypowiedzi uwidacznia się rozumienie małżeństwa jedynie jako konkretnego dnia, w którym dochodzi do zalegalizowania związku. Osoba wypowiadająca się nie odnosi małżeństwa do późniejszych etapów życia.

Pytania związane z posiadaniem dzieci spotkały się w jednym z przypadków $\mathrm{z}$ wzajemnie wykluczającymi się wypowiedziami. $\mathrm{Z}$ jednej strony dana kobieta opisuje posiadanie dzieci jako:

(W.2) „(...) fajny pomyst $w$ przysztości”.

Jednak w kolejnej wypowiedzi wyraża obawę przed bólem porodowym oraz odpowiedzialności za byt dziecka.

(W.2) „(...) to jest dużo pracy przy dzieciach. No nie wiem czy bym sobie poradzita, bo albo by mi je zabrali albo nie wiem".

Przytoczona wypowiedź świadczy o świadomości trudności sprawowania opieki nad dzieckiem oraz wiążącymi się z brakiem wypełniania tego obowiązku konsekwencjami. Kobieta zadaje sobie sprawę ze swoich ograniczeń odnoszących 
się do finansów, a także jej funkcjonowania. Co jednak nie przeszkadza jej w snuciu planów przyszłościowych związanych z macierzyństwem.

Pojęcia wierności i zaufania były dla większości badanym zrozumiałe. Potrafili konkretnie i rzeczowo zdefiniować dane zagadnienie. Zwracając uwagę na istotną rolę wierności $\mathrm{w}$ relacjach partnerskich.

(W.1) „Wierność, żeby z ta jedyna osobą być, aż do śmierci”.

Zaufanie zaś było często porównywanie do dochowania tajemnicy przez drugą osobę.

(W.5) "Jako ktoś komuś coś powie a ten się nie wygada".

Nie odnosiło się ono bezpośrednio do związków partnerskich, tak jak w przypadku zagadnienia wierności. Odnosiłam wrażenie, że poziom zrozumienia pojęcia zaufania dotyczy jego powierzchownego pojmowania jako „dochowania tajemnicy". W wypowiedziach brakuje ustosunkowania się do więzi partnerskich oraz kwestii związanych z poczuciem bezpieczeństwa.

Zagadnienia związane $\mathrm{z}$ homoseksualizmem nie były badanym zupełnie obce. W odpowiedzi na zadane pytanie jeden $\mathrm{z}$ wypowiadających się używał wulgarnych sformułowań. W jego postawie nie zauważyłam skrępowania podczas posługiwania się konkretnymi określeniami, dlatego mogę przypuszczać, iż używa ich on w życiu codziennym.

(W.4) „(...) niektórzy mówia na niego pedał... ale to kurczę inaczej się mówi... muszę sobie przypomnieć... ale nie przypomnę sobie... bo dziewczyny to lesbijki sq".

\section{Przebieg edukacji seksualnej wśród osób z niepełnosprawnością intelektualną w stopniu głębszym}

Z relacji uczestników wynika, iż sposoby przekazu odnosiły się do wyświetlania filmów instruktażowych, pracy na fantomach penisa oraz pochwy, a także zapoznania się ze specyfiką funkcjonowania noworodka przy pomocy interaktywnych lalek.

Treści przekazywane na zajęciach były ściśle związane z formami przekazu. Prezentowana tematyka poruszała kwestię budowy ciała, dojrzewania kobiety i mężczyzny oraz związanych z tym procesem zmian w ciele człowieka.

(W.1) „Byty filmy (...) to o seksuologii, miesiaczkach, byto o plemnikach, o penisie”.

Poruszana była także kwestia współżycia z drugą osobą oraz zapłodnienia.

(W.5) „O seksie (...) o zaptadnianiu jajeczek (...) skąd się biorą dzieci”. 
Skupiano się również na przekazaniu informacji dotyczących środków antykoncepcyjnych.

(W.2) „(...) bo kobieta się zabezpiecza różnymi technikami (...) są zastrzyki, sq plastry, są tabletki antykoncepcyjne, a mężczyzna to musi mieć prezerwatywy".

W programie zajęć przewidziano naukę zakładania prezerwatywy na fantom penisa.

(W.2) „Taki sztuczny penis co ma, co się zna i wtaśnie naktada na tego sztucznego".

Kolejny wątek poruszał zagadnienia dotyczące opieki nad dzieckiem. Odpowiedzialnością za jego rozwój oraz odpowiednią reakcją na zachowania niemowlęcia. Do przedstawienia tej tematyki posłużyła instruktorce interaktywna lalka. Dzięki, której kursanci mogli uświadomić sobie, czym wiąże się opieka nad małym dzieckiem.

(W.4) „No były różne takie, też było o dziecku mówione i pokazywała takie różne rzeczy (...) jak zajmować się dzieckiem".

(W.2) „No przyjechata z lalka, z ubrankami dla tej lalki, że jak dziecko przebiera karmi po kolei, gdzie się zatatwia (...)".

$Z$ relacji uczestników wynika, iż warsztaty trwały przez 3 dni. Każdy dzień przedstawiał odmienną tematykę przedstawioną powyżej. Zajęcia odbywały się $\mathrm{w}$ grupach mieszanych. Jedynie przy treściach związanych ze specyfiką dojrzewania obu płci grupa została rozdzielona.

(W.5) "No na chwilę zostaliśmy sami my a później one".

(W.2) „I było, że raz mieszane a raz, że same kobiety i potem dopiero ten partner ten mój z nami dopiero".

Mężczyznom przedstawiano wiadomości dotyczące budowy ciała i przebiegu okresu dojrzewania u kobiet. Zaś płci przeciwnej dostarczano informacji o rozwoju fizycznym mężczyzn.

Podczas rozmów osoby badane przedstawiły także charakterystykę edukacji psychoseksualnej odbywającej się na ternie Warsztatów Terapii Zajęciowej. Tematyka owych zajęci skupia się jedynie na rozróżnianiu emocji oraz rozmowy na ich temat.

(W.3) "No tylko o emocjach samych (zmiana modulacji głosu)".

(W.5) "No o tych minkach, emocjach..."

Formy zajęć w opinii osób badanych skupiają się na odgrywaniu scenek. Jedne z rozmówców opisuje przeprowadzany przez terapeutę test Sally-Ann, polegający na zdiagnozowaniu czy dana osoba posiada umiejętność wczuwania się w myśli i uczucia drugiej osoby. Przeprowadzenie testu polega na przedstawieniu 
przez badacza sytuacji, w której jedna z dziewczynek Sally ma koszyk, a druga Ann pudełko. Sally ma szklaną kulkę, którą wkłada do swojego koszyka. Następnie dziewczynka wychodzi. W tym czasie Ann wyjmuje kulkę i wkłada ją do swojego pudełka. Po chwili Sally wraca i chce bawić się swoją kulką. Badacz jest zobowiązany do zadania pytania osobie, która bierze udział w teście "Gdzie Sally będzie szukała swojej kulki?"1

Prawidłowa odpowiedzieć świadczy o umiejętności przyjmowania perspektywy drugiej osoby. Owy test można modyfikować dostosowując go do potrzeb badanych.

Jeden z badanych przyznaje, iż zajęcia mu się podobają, ale:

(W.5) "no trochę się nudzę na tych zajęciach (...) bo wszystko już wiem (...) sq̨ osoby, które nie wiedza".

Kolejny z rozmówców opowiada o edukacji seksualnej przeprowadzanej w szkole, do której uczęszczał. Zajęcia poruszały tematykę podobną do warsztatowej skupiającej się jednak bardziej na aspekcie emocjonalnym. Przekaz odbywał się w formie filmowej, a także słownej.

(W.4) „Z pania psycholog to mieliśmy (...) Też mieliśmy ... po prostu filmy puszczane... i to po prostu tak, że na tych filmach się tam uczyliśmy i opowiadaliśmy (...) podobne też tak jak na zajęciach tylko, że inaczej mowa byta".

Na zadane pytanie czy tutaj też się odbywają takie zajęcia, rozmówca odpowiedział:

(W.4) Yyynieee..."

\section{Percepcja edukacji seksualnej przez osoby z niepełnosprawnością intelektualną w stopniu głębszym}

Trzy na pięć osób badanych przyznały, iż podczas zajęć poczuły się zawstydzone prezentowanymi informacji. Wynikało to prawdopodobnie $\mathrm{z}$ otwartości z jaką instruktorka omawiała intymne zagadnienia.

Żaden z rozmówców nie wyraził opinii, aby przedstawiane treści w jakikolwiek sposób były dla nich śmieszne,. Określane były mianem „poważnych” lub też „smutnych”. Duży wpływ na jedną z uczestniczek wywarła kwestia porodu i związanego z nim bólu.

1 U. Frith, Autyzm- wyjaśnienie tajemnicy, Gdańskie Wydawnictwo Psychologiczne, 2008. 
(W.2) „Bardziej z bólem i cierpieniem, nie śmieszne też nie. Bardziej poważne. (...) Dla mnie to jest smutne, bo ja oglądałam kobietę, która też cierpiała, bo myślała, że urodzi w szpitalu, a urodziła gdzie indziej. I to jest właśnie bolesne".

Trudno jest określić, czy owe poczucie smutku wywołały zajęcia warsztatowe, na których był wyświetlany film. Czy też może jej odczucia odnosiły się fabularyzowanej historii, którą miała szansę oglądać poza warsztatami.

Na pytanie związane z konkretnymi treściami, jakie wywołały u jednej z uczestniczek poczucie zawstydzenia, odpowiadała w sposób wymijający, a także można była zauważyć zmianę modulacji głosu.

(W.3) "(...) No nie wiem (śmiech)...no nie wiem, że kobieta ma większy biust a chtopacy maja mniejszy (...) no, że maja na przykład, że ja mam na przykład, że chłopcy maja większe nogi, a kobiety mniejsze, tego tak nie mogę..."

O ile pierwsza z podanych informacji prawdopodobnie mogła w kobiecie wzbudzić poczucie wstydu to końcowe zdanie cytowanej wypowiedzi nie odnosi się do kwestii, które mogłyby nosić miano krępujących. Sądzę, iż osoba badana mogła nie zrozumieć kontekstu pytania lub też podawała informację, które nasunęły jej się jako pierwsze, nie zastanawiając się nad istotą zagadnienia.

Uczestnicy warsztatów charakteryzowali możliwości wzięcia udziału w zajęciach w sposób pozytywny. Większość osób wypowiadających się oświadczyła, iż forma ćwiczeniowa podobała im się. Jeden z uczestników stwierdził, że:

(W.1) "Podobało mi się, ale trochę nudno było".

Na pytanie związane z przyczyną owej monotonii stwierdził:

(W.1) „W kótko to samo wałkowanie (...) o tych miesiączkach”.

Wyżej przedstawione odczucie jednego z badanych może wynikać z przeświadczenia, iż wiedza, jaką posiada, jest wystarczająca i nie potrzebuje jej rozbudowywać. A także o braku zainteresowania tematem dojrzewania kobiety.

Większość z rozmówców wyraziła chęć kontynuacji zajęć o tematyce związane z ich seksualnością.

(W.3) "No bym chciała częściej (zmiana modulacji głosu)”.

(W.1) „Żeby częściej były tak. Żeby było mówione o tym".

Jedna z uczestniczek wyraziła obawę związaną ze zmianą osoby prowadzącej.

(W.2) „No to zależy od osoby, która prowadzi zajęcia.......) No bardzo miło było. Przyjeżdżała z akcesoriami i pokazywała nam różne rzeczy, co jest do czego. Bo jakby inna byta to nie wiadomo jak by było". 
Wyżej przedstawione opinie jednoznacznie przedstawiają podejście badanych do organizowania tego rodzaju warsztatów. Widzą oni potrzebę w zdobywaniu wiedzy na temat własnego ciała i relacji międzyludzkich. Dostosowanie form przekazu jest istotnym czynnikiem w zrozumieniu przez osoby z niepełnosprawnością intelektualną przekazywanych treści. Dzięki temu mogą oni łatwiej zobrazować sobie przybliżane im tematy.

Jednak pomimo wielu zalet organizowania takich warsztatów sądzę także, iż są one niewystarczające $\mathrm{w}$ stosunku do różnorodności problemów osób z niepełnosprawnością intelektualną. Uważam także, iż w obowiązku terapeutów jest wspieranie i dostarczanie wiarygodnych informacji rodzinom, które mają trudności z zaakceptowaniem seksualności swoich niepełnosprawnych dzieci.

\section{Następstwa edukacji seksualnej wśród osób $\mathrm{z}$ niepełnosprawnością intelektualną w stopniu głębszym}

Zorganizowanie spotkania z profesjonalnym edukatorem seksualnym pozwoliło uczestnikom poznać wiele aspektów seksualności, o których nie byli wcześniej uświadamiani. Wiedza osób biorących udział w badaniu charakteryzowała się różnorodnym poziomem jej przyswojenia. Niektóre z nich twierdziły, iż mało pamiętają z tego co działo się na warsztatach. Może być to faktycznym stanem, ponieważ przeprowadzone zajęcia przez dr Fornalik zapoczątkowały, ale i także zakończyły szeroko rozumianą edukację seksualną.

Brak kontynuacji warsztatów oraz wyjaśnienia niezrozumiałych kwestii pozostawia osoby z niepełnosprawnością intelektualną $\mathrm{w}$ trudnej sytuacji. W pewnym stopniu ich ciekawość została zaspokojona, ale dalsze rozważania są udaremnione przez prezentowane postawy terapeutów oraz braku systemowego rozwiązania dotyczącego edukacji seksualnej obejmującą populację osób z niepełnosprawnością intelektualną.

W przekonaniu osób badanych opisywane warsztaty pozwoliły im bliżej zapoznać się z aspektem rodzicielstwa, wpływem współżycia seksualnego na budowanie związku a także dostarczyły elementarnej wiedzy w zakresie budowy ciała mężczyzny i kobiety. Procesu zapłodnienia oraz środków antykoncepcyjnych.

(W.1) "Informacji petno. Dowiedziatem się, że nie wiedziatem jak to się robi, jak się postępuje (...) z dziewczyng (...) jak wptywa na zwiazek (...) seks".

(W.4) „We wszystkim (...) no tak po prostu (...) na zachowania patrzę inaczej...".

Dalsze wypowiedzi świadczą o tym, iż niektóre z prezentowanych pojęć warsztatowych nie były czymś nowym dla uczestników kursu. Zapytani o nowe informacje, z jakimi mogli się zapoznać podczas warsztatów, odpowiadali: 
(W.5) „Wszystko wiedziatem”. (W.4) „Niekoniecznie... już tam wiedziałem...”.

Jedna z kobiet zauważyła, iż Internet daje także dużo możliwości związanych z poszukiwaniem informacji dotyczących seksualności.

(W.2) „(...) bardziej korzystam z Internetu. Można się dowiedzieć wielu rzeczy, o czym tu teraz rozmawiamy".

Przytoczona wypowiedź potwierdza jedynie zasadność wprowadzenia edukacji seksualnej do szkół oraz wszelkich placówek, w których przebywają dorosłe osoby z niepełnoprawnością intelektualną. Zebrany materiał empiryczny jasno sygnalizuję potrzebę uświadomienia oraz uzyskania odpowiedzi na nurtujące pytania ze strony zainteresowanych osób.

Celem organizowanych warsztatów jest nie tylko przybliżenie informacji związanych z seksualnością, ale także pokazanie w jaki sposób terapeuci i opiekunowie mogą rozmawiać oraz przekazywać konkretną wiedzę. Jednak pomimo coraz większej dyskusji naukowej wokół tematów powiązanych z intymną sferą relacji międzyludzkich $\mathrm{w}$ odniesieniu do przeżyć osób $\mathrm{z}$ niepełnosprawnością intelektualną, wciąż sfera seksualności jest pojmowana w bardzo wąskim znaczeniu. Terapeuci nie są przygotowani, ale także i nie wyrażają chęci na zmianę myślenia o normalizacji życiu swoich podopiecznych. Wolą prezentować dobrze znaną, komfortową postawę, charakteryzującą się interwencją terapeutyczną podczas sytuacji problemowej. Takie działania, jeżeli przynoszą, efekt to są one skoncentrowane na chwilowym załagodzeniu zaistniałej sytuacji. Uwidacznia się brak refleksji związanej z przyczyną danego zachowania oraz bagatelizowanie istotnej sfery życia ludzkiego, jaką jest seksualność.

\section{Zakończenie}

Każdy z badanych podkreślał, iż seksualność jest to istotna sfera ich życia. Zaś ich poszczególne poglądy były bezpośrednio związane z osobistymi doświadczeniami bądź wnioskami wyciągniętymi z rodzinnych sytuacji oraz rozmów. Aby uzyskać odpowiedź na postawiony przeze mnie problem badawczy musiałam najpierw zapoznać się z poziomem wiedzy na temat podstawowych kwestii związanych z fizycznością oraz zagadnień, których rozumienie pozwala na budowanie stałego i wartościowego związku partnerskiego.

Kwestie związane ze zmianami zachodzącymi w organizmie człowieka podczas okresu dojrzewania były osobom wypowiadającym się znane. Jednak ich rozumienie nie pokrywało się ze używanym słownictwem. 
Zagadnienia dotyczące różnorodności pod względem fizycznym i psychicznym obu płci były wymieniane przez większość z badanych. Jednak tylko jedna z osób, która zadeklarowała aktywność seksualną, była w stanie powiązać poszczególnych części ciała z bezpośrednim aktem seksualnym. Zapewne związane jest to $\mathrm{z}$ jej doświadczeniami $\mathrm{w}$ tej sferze życiowej. Pozostali badani nie odnosili przedstawianych informacji do seksu. Zaś sam stosunek seksualny osoby wypowiadające się opisywały pod względem technicznym. Nie odnosiły się do emocjonalnych doznań. Tylko jedna osoba zwróciła uwagę na ważność przyzwolenia obydwu stron na zaangażowanie się w daną aktywność seksualną.

Zagadnienia bezpośrednio powiązane z kwestią zaufania oraz wierności były porównywane do powierzenie tajemnicy drugiej osobie. Osoby wypowiadające się odnosiły to pojęcie do relacji partnerskich. Brak dotrzymania wierności łączył się ze zdradą, która w rozumieniu większości badanych oznaczała fizyczne oddanie się drugiej osobie. Kwestia intymności całkowicie nie była rozumiana przez osoby z niepełnosprawnością intelektualną. Większość z badanych nie potrafiła zdefiniować podanego zagadnienia, a także nie odnosili go do żadnej ze sfery życiowej. Tylko jedna z osób wypowiadających się określiła intymność jako moment, w którym para ludzi angażujących się w aktywność seksualną musi zaprzestać ze względu na możliwość zaistnienia sytuacji „przyłapania” przez inną osobę.

Pytania skupiające się na kwestiach założenia rodziny, małżeństwa oraz rodzicielstwa miały na celu zapoznanie się z opiniami osób z niepełnosprawnością intelektualną w stopniu głębszym na podane tematy. Wszyscy badani założenie rodziny oraz wstąpienie w związek małżeński warunkowali potrzebą usamodzieInienia się od rodziców oraz możliwości podjęcia pracy zarobkowej. Przedstawione warunki były według opinii osób wypowiadających się niezbędne do tworzenie własnego pełnowartościowego życia. Świadomość ograniczeń prawnych oraz osobistych nie pozwoliła badanym na deklarację chęci wstąpienie w związek małżeński, a także podjęcia się opieki nad własnych potomstwem. Posiadanie dziecka przez osoby z niepełnosprawnością intelektualną było z jednej strony bezpośrednio związane z dużą odpowiedzialnością za czyjeś wychowanie a z drugiej traktowane jako ciekawa prospektywna na przyszłość. Wynika z tego stwierdzenia zaprzeczenie, które ewidentnie świadczy o braku pełnej świadomości konsekwencji związanych z założeniem rodziny i rodzicielstwem.

Przedstawiając powyższe podsumowanie wypowiedzi osób badanych na istotne kwestie, które warunkują rozumienie, a co za tym idzie, nadawanie znaczeń przez osoby z niepełnosprawnością intelektualną seksualności świadczy o ich powierzchownej wiedzy. W swoich wypowiedziach pomijają aspekt emocjonalny skupiając się jedynie na elementach technicznych. Z jednej strony deklarują świadomość swoich ograniczeń, a z drugiej zaś strony nie zaprzestają wiązać 
swojej przyszłości $\mathrm{z}$ w ich opinii niedostępnymi sferami życiowymi. Odniosłam wrażenie, że niektóre z wypowiedzi osób z niepełnosprawnością intelektualną są zlepkiem przekonań i opinii innych osób. Zaś sami badani, próbując wpasować się w ramy społeczeństwa w jakim funkcjonują, starają się przyjąć postawy najbardziej preferowane przez osoby je otaczające.

Wszyscy badani wyrazili aprobatę dla organizowania spotkań, których celem jest opowiedzenie i uświadomienie osobom niepełnosprawnych kwestii związanych z intymnymi sferami życiowymi. Na pytanie związane z intencjonalnością spotkań o takim charakterze osoby wypowiadające się zauważyły potrzebę posiadania wiedzy związanej ze zmianami zachodzącymi we własnym ciele oraz zwrócenie uwagi na niezbędne aspekty życiowe, które pozwolą uczestnikom budować trwałe związki partnerskie. Każda z osób badanych w inny sposób reagowała na otwartą rozmowę o kwestiach intymnych ich życia. Zachowania podczas wywiadów przybierały charakter od postawy osoby bardzo zawstydzonej poprzez obojętną do otwartej na rozmowę. Każdy z uczestników odznaczał się odmienną świadomością własnej seksualności, co przekładało się bezpośrednio na zrozumienie i odbieranie informacji, jakie dostarczało uczestnikom szkolenie. Sądzę, iż opisywane spotkanie z dr Izabelą Fornalik miało dla osób badanych charakter zajęć, na którym niektórzy z nich mogli dowiedzieć się nowych informacji bądź spojrzeć na swój związek z innej perspektywy. Jednak brak cykliczności szkoleń nie pozwolił uczestnikom owych wiadomości przełożyć na własne życie i doświadczenia. Była to dla nich pewnego rodzaju lekcja, której brak kontynuowania nie zapewnił zmian w ich życiu.

Jak wykazały przeprowadzone badania w placówkach wspomagających osoby z niepełnosprawnością intelektualną nie odbywają się cykliczne zajęcia poruszające tematykę seksualności. W jednej z placówek organizowane są spotkania mające na celu wyjaśnienie problemów zaistniałych w danej grupie. Opierają się one na rozmowach o przeżyciach dnia codziennego uczestników warsztatów. Wszelkie sytuacje związane z przejawianiem zachowań seksualnych są konsultowane na indywidualnych spotkaniach z samą osobą zainteresowaną oraz jej rodzinom. Wypowiadająca się terapeutka określa wyżej opisane działania jako doraźne i niespełniające funkcji edukacyjnej. Jedynie odnoszą się do konkretnej zaistniałej sytuacji. Pomimo posiadania w placówce wykwalifikowanego edukatora seksualnego, Warsztaty Terapii Zajęciowej nie prowadzą zajęć o charakterze edukacji seksualnej. Terapeutka widzi potrzebę wprowadzenia takich zajęć, jednak w jej opinii bez wsparcia systemowego żadne zmiany nie są możliwe.

W drugiej z opisywanych placówce terapeutka deklaruje prowadzenie zajęć z psychoedukacji seksualnej. Jednak jej relacja oraz uczestników zajęć sprowadza owe spotkania do rozmów i identyfikacji czterech podstawowych emocji. Zaś organizowane dramy w opinii prowadzącej mają na celu zwrócenie uczestnikom 
uwagi na zjawisko wykorzystywania seksualnego i ich odpowiednią reakcję w sytuacjach problemowych. Jednak z relacji terapeutki zajęcia te każdorazowo przebiegają w ten sam sposób. Uczestnicy zajęć odgrywają tę samą scenkę. Co w mojej opinii w żaden sposób nie oddziałuje na odbiorców warsztatów, gdyż traktują oni te spotkania jako zabawę i nie mają świadomości przełożenia ćwiczonej sytuacji na prawdziwe życie. Zachowania osób z niepełnosprawnością intelektualną rzutują na opinię terapeutki o braku możliwości przyswojenia przez jej podopiecznych podstawowych umiejętności obronnych.

Jedyną formą edukacji seksualnej badanej przez mnie grupy osób z niepełnosprawnością intelektualną są jednorazowe szkolenia organizowane przez dr Izabelę Fornalik. Zajęcia te poruszają tematykę zmian zachodzących $\mathrm{w}$ ciele kobiety i mężczyzny podczas okresu dojrzewania. Tłumaczą kwestię zapłodnienia, masturbacji oraz poruszają kwestię rodzicielstwa. Prezentowane treści są przekazywane w sposób konkrety i możliwy do przyswojenia przez osoby z niepełnosprawnością intelektualną w stopniu głębszym. Opierając się m.in. na fantomach narządów płciowych kobiety i mężczyzny oraz interaktywnych lalek tłumaczone są powyżej opisane treści szkolenia.

Kolejna sfera przeprowadzonych badań odnosi się do następstw edukacji seksualnej wśród osób z niepełnosprawnością intelektualną w stopniu głębszym. Próbę odpowiedzi na podaną kwestię muszę odnieść jedynie do jednorazowego szkolenia, w jakim uczestniczyły osoby badane. Zapytane o wykorzystywanie informacji zebranych podczas spotkania w życiu codziennym, większość z nich nie przejawiała przenoszenia zdobytej wiedzy na rzeczywiste problemy bądź sytuacje wywołujące u nich poczucie zakłopotania. Entuzjastycznie podchodzili do możliwości kolejnego uczestnictwa w tego typu spotkaniu. Jednak nie potrafili określić jakiego typu informacje były by dla nich przydatne, a także jakie wiadomości wykorzystali po odbyciu kursu.

$\mathrm{W}$ opinii terapeutów jednorazowe spotkania nie są w stanie zmienić niczego w świadomości osób z niepełnosprawnością intelektualną. Jedna z terapeutek posiada także zastrzeżenia związane $\mathrm{z}$ formą przekazania owych treści samym uczestnikom. Uważa, iż nie są one odpowiednio dostosowane do ich możliwości poznawczych. Argumentując, iż każda z osób funkcjonuje na innym poziomie poznawczym oraz językowym. Zarzuca także, iż tematyka zajęć opiera się jedynie na technicznych aspektach seksualności, których osoby z niepełnosprawnością nie są $\mathrm{w}$ stanie rozumieć po sporadycznym spotkaniu z edukatorem seksualnym.

Jestem w stanie zgodzić się z przesłankami związanymi z brakiem efektywności zajęć wynikających z ich sporadyczności. Jednak zamknięta postawa środowiska bezpośrednio związanego z osobami z niepełnosprawnością intelektualną jest dla mnie niezrozumiała. Oczywistym wydaje się działanie, którego celem byłaby kontynuacja warsztatów dr Fornalik. Pomimo uczestnictwa w szkoleniu odnoś- 
nie do przekazywania podopiecznym treści związanych z ich sferą intymną, żadna z terapeutek nie podjęłaby się poprowadzenia takich zajęć.

Analiza problemowa przeprowadzonych badań empirycznych świadczy o braku systemowych rozwiązań dotyczących edukacji seksualnej dla osób z niepełnosprawnością intelektualną. Pomimo dyskusji naukowej oraz społecznej wokół tej tematyki życia osób z niepełnosprawnością intelektualną, wciąż zauważa się postawy odznaczające się brakiem akceptacji realizacji potrzeb seksualnych przez niepełnosprawnych członków społeczeństwa.

Zaś sami zainteresowani widzą dużą potrzebę rozmawiania na tematy poruszające kwestie intymne ich życia. Osoby z niepełnosprawnością intelektualną często wiążą się w związki partnerskie, które po krótkim czasie kończą się. Może to świadczyć m.in. o braku zrozumienia potrzeb drugiej osoby, bądź o trudnościach związanych z ich emocjonalnością. Dlatego też kwestia edukacji seksualnej jest istotnym czynnikiem, który pomoże $\mathrm{w}$ zrozumieniu potrzeb płynących z własnego ciała, radzeniem sobie z napięciem seksualnym. Daje także możliwość na doświadczanie świadomej miłości i przeżywania jej wszystkich aspektów. Warunkuje pozytywne postrzeganie własnej osoby, co stanowi o akceptacji i zrozumienia swoich możliwości oraz ograniczeń.

Wyżej przedstawione wnioski z przeprowadzonych badań mogą świadczyć o potrzebie wprowadzenia edukacji seksualnej do wszystkich placówek zajmujących się edukowaniem innych osób. Ważną kwestią jest dostrzeżenie oraz akceptacja faktu, który wiąże się z możliwością przeżywania własnej seksualności przez każdego człowieka. Seksualność jest nieodłącznym elementem budowania obrazu własnej osoby. Jej ograniczenia oddziałują na pozostałe sfery życia ludzkiego. Edukacja seksualna może pomóc w zrozumieniu własnego ciała oraz psychiki. Kształtuje również postawę otwartości i zrozumienia, których brakuje w polskim społeczeństwie, a jednocześnie daje szansę na prowadzenie satysfakcjonującego życia przez każdego człowieka. 